\title{
Suppression of Helicobacter pylori reduces gastrin releasing peptide stimulated gastrin release in duodenal ulcer patients
}

\author{
K Beardshall, S Moss, J Gill, S Levi, P Ghosh, R J Playford, J Calam
}

\begin{abstract}
Helicobacter pylori increases gastrin release in duodenal ulcer patients. This may be through disruption or changes in the mucus layer affecting the access of luminal stimulants to gastrin releasing cells. The effect of suppressing $\boldsymbol{H}$ pylori on gastrin release stimulated by a non-luminal stimulus, gastrin releasing peptide (GRP), was examined. Eleven patients with active duodenal ulcer disease and colonised with $H$ pylori received an intravenous infusion of GRP (2.9 pmol $/ \mathrm{kg} /$ minute for 30 minutes) and the plasma gastrin response was measured. Basal and peak pentagastrin stimulated acid output were also determined. Patients were treated with tripotassium dicitratobismuthate (De-Nol) and metronidazole to suppress $H$ pylori and the tests were repeated. Suppression of $\boldsymbol{H}$ pylori decreased plasma gastrin concentrations during GRP infusion, but acid output was not affected. Chromatographic analysis of the forms of gastrin in plasma showed a significant fall in gastrin 17, the predominant form found in the gastric antrum. Gastrin 34 did not fall significantly. This study shows that suppression of $\boldsymbol{H}$ pylori decreases the hypergastrinaemia caused by the nonluminal stimulant, GRP, mainly via decreasing gastrin 17.
\end{abstract}

Duodenal ulcer disease is strongly associated with gastric colonisation with Helicobacter pylori. ${ }^{1-4}$ We reported that $H$ pylori increases release of the antral hormone gastrin in these patients. $^{56}$ This may explain the raised postprandial gastrin release ${ }^{7}$ and gastric acid secretion seen in duodenal ulcer disease..$^{8-10}$ Several mechanisms have been proposed to explain how $H$ pylori increases gastrin release. $H$ pylori may specifically increase gastrin release in response to luminal stimulants. For example, either disruption $^{11}$ or alkalinisation ${ }^{12}$ of the gastric mucus layer by $H$ pylori could increase the access of luminal stimulants to gastrin releasing cells. Patients with hypergastrinaemic duodenal ulcer disease have increased sensitivity to luminal stimulants of gastrin release ${ }^{13}$ and so far studies of the effects of $H$ pylori on gastrin release have used only food as the stimulus, ${ }^{5614}$ and this stimulates gastrin 17 predominantly. ${ }^{15} \mathrm{We}$ therefore examined the effect of suppressing $H$ pylori on the release of gastrin stimulated by intravenous infusions of the non-luminal stimulant gastrin releasing peptide (GRP) - a peptide that is normally present in nerve fibres within the gastric antrum. ${ }^{16-18}$. We also studied the molecular forms of the plasma gastrin response to
GRP to determine whether this was affected by $H$ pylori colonisation.

\section{Methods}

The study was approved by the local ethics committee and all patients gave informed consent. Eleven patients, three women and eight men aged 27-60 years (mean 43), took part. They all had active duodenal ulcer disease and a positive biopsy urease test for $H$ pylori on entry. Histological examination of antral biopsy specimens stained with haematoxylin and eosin showed $H$ pylori like organisms in all cases.

Within one week of endoscopy, when the patients had been off all therapy for at least four days, they were given a standard test of gastric acid output using stimulation by pentagastrin infusion with correction for pyloric losses, as described previously. ${ }^{58}$ They also received an intravenous infusion of GRP (Cambridge Research Biochemicals, Cambridge, UK), $2.9 \mathrm{pmol} / \mathrm{kg} / \mathrm{minute}$ for 30 minutes, and blood samples were collected for gastrin assay at the times shown in Figure 1.

Patients then received tripotassium dicitratobismuthate(De-Nol tabs) $120 \mathrm{mg}$ four times daily for four weeks, with metronidazole $400 \mathrm{mg}$ four times daily for the first two weeks of treatment.

Endoscopy was repeated within one week of completing this therapy, and the studies of pentagastrin stimulated acid output and GRP stimulated gastrin release were repeated within one week of endoscopy.

Blood for gastrin assay was collected into

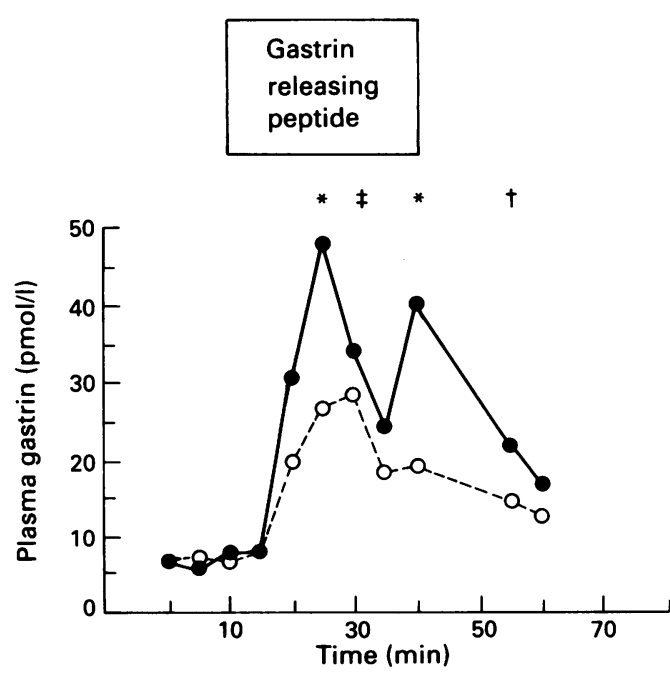

Figure 1: Median plasma gastrin concentrations (pmol/l) during iv gastrin releasing peptide infusion $(2.9 \mathrm{pmol} / \mathrm{kg}$ minute) before (- - ) and after (……) treatment to suppress Helicobacter pylori. ${ }^{\star} p<0.05, \dagger p<0.01$, $\neq p<0.005$. 


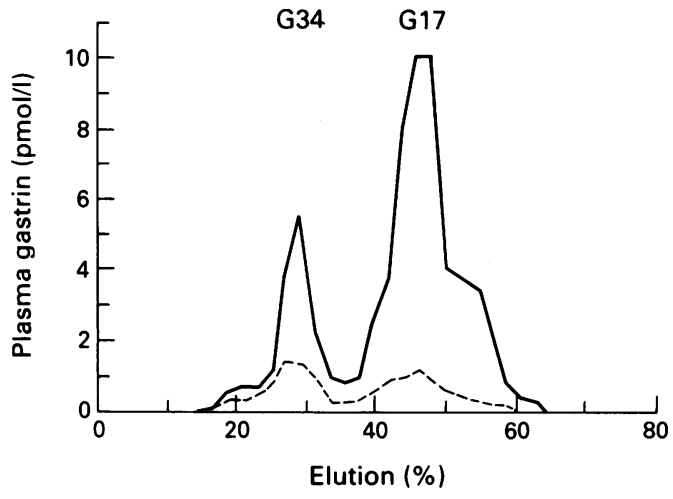

Figure 2: Gastrin immunoreactivity eluting from Sephadex G50 chromatography column of $1 \mathrm{ml}$ plasma before (-) and after (…) treatment. A representative patient. G17=gastrin 17; G34= gastrin 34 .

chilled tubes containing disodium EDTA ( $2 \mathrm{mg}$ / $\mathrm{ml}$ of blood). Plasma was separated promptly and stored at $-20^{\circ} \mathrm{C}$ until further analysis. Gastrin was measured in plasma samples by radioimmunoassay using antibody $\mathrm{G} 179$, provided by Professor Bloom. ${ }^{5}$ Plasma samples with the highest GRP stimulated gastrin concentrations for each patient were further analysed by chromatography on $1 \times 100 \mathrm{~cm}$ Sephadex G50 superfine columns (Pharmacia, Uppsala, Sweden), eluted with $0.05 \mathrm{~mol} / \mathrm{l}$ ammonium bicarbonate containing $0.05 \%$ sodium azide, $\mathrm{pH} 8.4$, at $4^{\circ} \mathrm{C}$ and $0.2 \mathrm{ml} /$ minute. Eluates were dried by centrifugal evaporation (Savant, Farmingdale, NY, USA) in the assay tubes before gastrin radioimmunoassay.

Statistical analysis was by Wilcoxon's matched pairs test.

\section{Results}

\section{PLASMA GASTRIN CONCENTRATIONS}

Median plasma gastrin concentrations during infusion of GRP were significantly lower after the anti- $H$ pylori treatment at most time points. (Fig 1). A biphasic gastrin response to the GRP infusion is evident. The integrated plasma gastrin response was also significantly lower after treatment. Before treatment the median integrated gastrin response was 1007 (range 312-3579) pmol.min/l, this fell to 429 (153-1903) after treatment, $\mathrm{p}<0.01$.

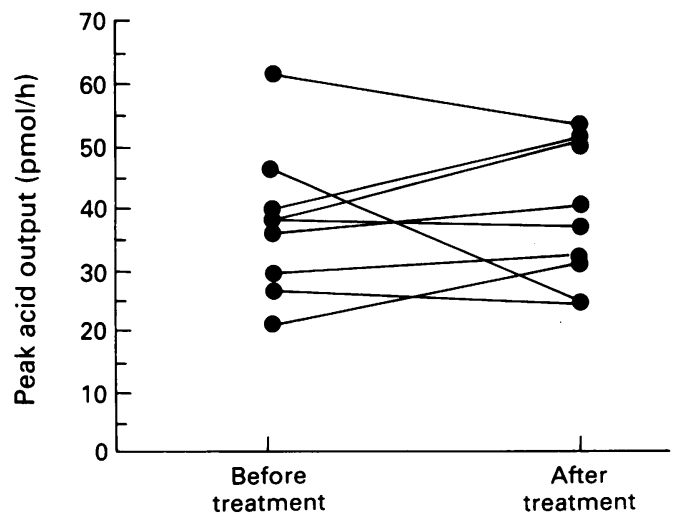

Figure 3: Peak pentagastrin stimulated gastric acid output before and after treatment.
CHROMATOGRAPHY OF FORMS

Gastrin immunoreactivity eluted from the gel filtration columns in two peaks corresponding to gastrin 34 and gastrin 17 (Fig 2). After suppression of $H$ pylori there was a significant fall in gastrin 17 from a median of 30 (range 4-207) to 5 (1-24) pmol/l, p <0.01. Gastrin 34 fell to a lesser extent, from a median of $8(2-65)$ to 4 (2-6) $\mathrm{pmol} / \mathrm{l}$ but the change in this form did not reach statistical significance.

\section{GASTRIC ACID SECRETION}

Basal acid output and peak pentagastrin stimulated acid output were not significantly affected one month after the start of treatment to suppress $H$ pylori (Fig 3). Median basal acid output was 3.7 (range $0 \cdot 3-26 \cdot 5$ ) $\mathrm{mEq} / \mathrm{hour}$ before treatment and $2 \cdot 9(0 \cdot 7-13 \cdot 9(\mathrm{mEq} /$ hour afterwards. Median peak acid outputs were $37 \cdot 4(20 \cdot 9-61 \cdot 3)$ and $36 \cdot 5$ $(23.6-53.0) \mathrm{mEq} /$ hour before and after treatment respectively.

\section{Discussion}

In this study we have shown for the first time that suppression of $H$ pylori by De-Nol and metronidazole leads to a fall in the release of gastrin stimulated by a non-luminal stimulus. This stimulant was GRP, which is present in nerve fibres in the gastric antrum ${ }^{16-18}$ and is capable of stimulating gastrin release at very low doses. ${ }^{19}$ GRP is closely related to the frog skin peptide, bombesin, and therefore gastric colonisation with $H$ pylori may be responsible for the increased gastrin response to bombesin in patients with duodenal ulcer disease..$^{20}$

The finding of enhanced GRP stimulated gastrin release in duodenal ulcer disease does not support the idea that $H$ pylori increases gastrin release purely by enhancing access of luminal stimulants to gastrin releasing cells, either through disruption ${ }^{11}$ or alkalinisation ${ }^{12}$ of the mucus layer.

There are alternative explanations for the phenomenon. Firstly, $H$ pylori might increase gastrin release through its urease enzyme releasing alkaline ammonia, raising the $\mathrm{pH}$ within the antral mucus layer and thus preventing inhibition of gastrin release by low intraluminal $\mathrm{pH}$. $^{5} \mathrm{We}$ are not aware of any studies of the effect of GRP (or bombesin) on gastrin release in patients with chronically raised intragastric $\mathrm{pH}$, but these patients have increased gastrin responses to other stimuli, including food ${ }^{21}$ and calcium infusion, ${ }^{22}$ suggesting that chronic alkalinisation of the antrum by $H$ pylori might also increase the response to GRP. Secondly, it has been suggested that $H$ pylori increases gastrin release by causing local inflammation, since basal gastrin concentrations are raised in patients with non- $H$ pylori antritis, ${ }^{23}$ and the cytokines $\gamma$ interferon and interleukin- 2 stimulate gastrin release from the isolated perfused dog antrum. ${ }^{2+}$ There have been no studies of this putative effect of inflammation on the release of gastrin by various stimulants. If inflammation does indeed increase the release of gastrin it might be expected that the effect would be non-specific and would include the response to GRP. 
De-Nol has a number of effects on gastric physiology apart from its anti- $H$ pylori effect. These include stimulating prostaglandin synthesis, increasing gastric mucus secretion, and coating the ulcer crater. ${ }^{25}$ It is therefore possible that the changes in gastrin observed after treatment may not be related to suppressing $H$ pylori at all, though this remains the most likely explanation.

The study of the effect of suppression of $H$ pylori on the different circulating forms of gastrin was undertaken because gastrin 34 is the predominant form in the duodenum whereas antral gastrin is mainly in the form of gastrin $17 .{ }^{26}$ Since $H$ pylori has been regarded as a stimulant of antral gastrin release, ${ }^{5}$ clearance of $H$ pylori might be expected to affect gastrin 17 more than gastrin 34. Our results indicate that this is the case - gastrin 17 fell significantly after treatment whereas the fall in gastrin 34 was less marked.

The lack of effect of suppression of $H$ pylori on basal and peak acid output over a four week period is consistent with the findings of our previous study. ${ }^{6}$ It remains to be seen whether prolonged absence of the organism eventually leads to a fall in peak acid output, which is a measure of the parietal cell mass, due to withdrawal of the trophic effect of gastrin. ${ }^{27}$ Results obtained by McColl show that in the short term clearance of $H$ pylori reduces postprandial gastric acidity ${ }^{1+}$ which is dependent on the stimulation of acid secretion by gastrin. ${ }^{28} 29$

Further studies are required to determine the mechanism by which $H$ pylori increases human gastrin release.

We are grateful to Sister L Francis-Reme and her staff for assistance with these studies, to The Wellcome Trust for financial assistance with these studies, to The Wellcome Trust for financial
support for KB as a research officer, and to the Medical Research support for $\mathrm{KB}$ as a research officer, and to the Medical
Council for supporting RJP as an MRC research fellow.

Part of this work has been published in an abstract (Gut 1990; 31: A597)

1 Dooley CP, Cohen H. The clinical significance of Campylobacter pylori. Ann Intern Med 1988; 108: 70-9.

2 Coghlan JG, Gilligan D, Humphreys $\mathrm{H}$, et al. Campylobacter pylori and recurrence of duodenal ulcers: a 12 months pylori and recurrence of dudy. Lancet 1987; ii: 1109-11.

3 Marshall BJ, Goodwin CS, Warren JR, et al. Prospective double-blind trial of duodenal ulcer relapse after eradication double-blind trial of duodenal ulcer relapse after era

4 Rauws EA, Tytgat GN. Cure of duodenal ulcer associated with eradication of Helicobacter pylori. Lancet 1990; 335: 1233-5.

5 Levi S, Beardshall K, Haddad G, Playford R, Ghosh P, Calam J. Campylobacter pylori and duodenal ulcer: the gastrin link. Lancet 1989; i: 1167-8.
6 Levi S, Beardshall K, Swift I, et al. Antral Campylobacter pylori, hypergastrinaemia and duodenal ulcers: effect of eradicating the organism. $B M \mathcal{F}$ 1989; 299: 1504-5.

7 Taylor IL, Dockray GJ, Calam J, Walker RJ. Big and little gastrin responses to food in normal and ulcer subjects. Gut 1979; 20: 957-62

8 Baron JH. Clinical tests of gastric secretion. Oxford: Oxford University Press, 1978 .

9 Lam SK, Ong GB. Identification of two subgroups of familial early-onset duodenal ulcers. Ann Intern Med 1980; 93: 540-6.

10 Malagelada JR, Longstreth GF, Deering TB, Summerskill WH, Go VL. Gastric secretion and emptying after ordinary meals in duodenal ulcer. Gastroenterology 1977; 73: 989-93.

11 Sidebotham RL, Baron JH. Hypothesis: Helicobacter pylori, urease, mucus, and gastric ulcer. Lancet 1990; 335: 193-5.

12 Lichtenburger LM, Nelson AA, Graziani LA. Amine trapping: physical explanation for the inhibitory effect of gastric acidity on the postprandial release of gastrin. Gastroenterology 1986; 90: 1223-31.

13 Cooper RG, Dockray GJ, Calam J, Walker RJ. Acid and gastrin responses during intragastric titration in normal gastrin responses during intragastric titration in normal
subjects and duodenal ulcer patients with G-cell hyperfunction. Gut 1985; 26: 232-6.

14 McColl KE, Fullarton GM, El Nujumi AM, Macdonald AM, Brown IL. Lowered gastrin and gastric acidity after eradication of Campylobacter pylori in duodenal ulcer. Lancet 1989; ii: $499-500$

15 Walsh JH. Gastrointestinal Hormones. In: Johnson LR, ed. Physiology of the gastrointestinal tract. 2nd ed. New York: Raven Press, 1987: 181-253.

16 Knuhtsen S, Holst JJ, Knigge U, Olesen M, Nielsen OV. Radioimmunoassay pharmacokinetics and neuronal release of gastrin-releasing peptide in anaesthetized pigs. Gastroof gastrin-releasing peptide
enterology 1984; 87: 372-8.

17 Dockray GJ, Vaillant C, Walsh JH. The neuronal origin of bombesin-like immunorectivity in the rat gastrointestinal tract. Neuroscience 1979; 41: 1561-9.

18 Buffa R, Solovieva I, Fiocca R, et al. Localisation of bombesin and GRP (gastrin releasing peptide) sequences in gut nerves or endocrine cells. Histochemistry 1982; 76: 457-67.

19 Varner AA, Modlin IM, Walsh JH. High potency of bombesin for stimulation of human gastrin release and gastric acid secretion. Regul Pept 1981; 1: 289-96.

20 Hirschowitz BI, Tim LO, Helman CA, Molina E. Bombesin and gastrin-17 dose responses in duodenal ulcer and controls. Dig Dis Sci 1985; 30: 1092-103.

21 Yalow RS, Berson SA. Further studies on the nature of immunoreactive gastrin in human plasma. Gastroenterology 1971; 60: 203-214.

22 Turnipseed WD, Keith LM. Altered serum gastrin levels in achlorhydric states. Am F Surg 1976; 131: 175-7.

23 Wyatt JI, Rathbone BJ, Green DM, Primrose J. Raised fasting serum gastrin in chronic gastritis is independent of Campylobacter pylori status and duodenal ulceration. Gut $1989 ; 30$. A1483.

24 Teichmann RK, Pratschke E, Grab J, Hammer C, Brendal W. Gastrin release by interleukin-2 and gamma-interferon in Gastrin release by interleukin-2 and gamma-interf
vitro. Can $\mathcal{A}$ Physiol Pharmacol 1986; 64 (suppl): 62 .

25 Hall DWR. Review of the modes of action of colloidal bismuth subcitrate. Scand $\mathcal{F}$ Gastroenterol 1988; 24 (suppl 157): 3-6.

26 Calam J, Dockray GJ, Walker R, Tracey HJ, Owens D. Molecular forms of gastrin in peptic ulcer: comparison of serum and tissue concentrations of G17 and G34 in gastric and duodenal ulcer subjects. Eur F Clin Invest 1980; 10: 241-7.

27 Johnson LR. The trophic action of gastrointestinal hormones. Gastroenterology 1976; 70: 278-82.

28 Feldman M, Walsh JH. Wong HC. Role of gastrin heptadecapeptide in the acid secretory response to amino acids in man. 7 Clin Invest 1978; 52: 308-13.

29 Maxwell V, Eysselein V, Kleibeuker J, Reedy T, Walsh JH. Glucose perfusion intragastric titration. Dig Dis $S c i 1984$; 29: 321-6. 